\title{
Multipurpose Catheter Modification for Entering Pulmonary Artery in a Complex Congenital Heart Disease
}

\author{
Vivek Kumar ${ }^{1 *}$, Jaimin Dave ${ }^{2}$ and Naveen Aggarwal ${ }^{3}$ \\ ${ }^{1}$ Pediatric Cardiologist, Army Hospital R \& R, India \\ ${ }^{2}$ Senior Resident Cardiology, Army Hospital $R \&$ R, India \\ ${ }^{3}$ Consultant and HOD Cardiology, Army Hospital R \& R, India \\ Submission: March 22, 2018; Published: May 24, 2018 \\ *Corresponding author: Vivek Kumar, Pediatric Cardiologist, Army Hospital R \& R, Delhi Cantt-110010, India -208004, Tel: 91-7042743322; \\ Email: vk3532@gmail.com
}

\begin{abstract}
Pulmonary artery (PA) pressure measurement during diagnostic catheterization in univentricular heart, is the most important parameter for single ventricle palliation. Many a times it is extremely difficult to enter the pulmonary artery because of the complex anatomy. Absence of atrial septal defect (ASD) precludes taking of reverse pulmonary venous wedge pressure as a surrogate marker for PA pressure. We encountered a similar problem; however it was circumvented by the modification of the multipurpose catheter.
\end{abstract}

Keywords: Multipurpose catheter; Pulmonary artery; Single ventricle

\section{Case Report}

A 9 year old male child was palliated with pulmonary artery (PA) band done at 4 month of age for double inlet left ventricle (DILV), outlet chamber on left with L-malposed great arteries and severe PAH. He had class II symptoms. On examination his weight was $25 \mathrm{~kg}$ and height was $132 \mathrm{~cm}$. He was saturating $88 \%$ in room air and the blood pressure was $100 / 50 \mathrm{mmHg}$. Cardiovascular examination revealed normal S1, single and soft S2 with ejection systolic murmur grade $4 / 6$. His echo showed DILV, outlet chamber anteriorly on the left giving rise to aorta and PA band in situ with gradient across PA band $70 \mathrm{mmHg}$. After discussion with the parents it was decided to do cardiac catheterisation to assess PA pressure and suitability for single ventricle palliation.

After taking consent patient was taken up for the procedure. Right femoral artery and venous access was taken with $5 \mathrm{Fr}$ sheath. As there was no ASD invasive pulmonary artery pressure had to be taken. Pulmonary artery was entered with 035" exchange length hydrophilic wire (terumo) over 5Fr end hole long curve multipurpose catheter (MPA), however neither Judkins right or multipurpose catheter could track over the wire taking two bends. We did not have slip catheters. We then decided to cut the $5 \mathrm{Fr}$ multipurpose catheter at the junction of primary and secondary curve and the secondary curve was also straightened (Figure 1).
This catheter was then slipped over the exchange length terumo wire with slight traction and counter traction (Figure $2 \& 3$ ). We easily entered PAs and pressure was taken which was $24 \mathrm{mmHg}$ (mean). It was decided after the procedure that the patient was not fit for single ventricle palliation so he was discharged with advise to be on medical follow up.

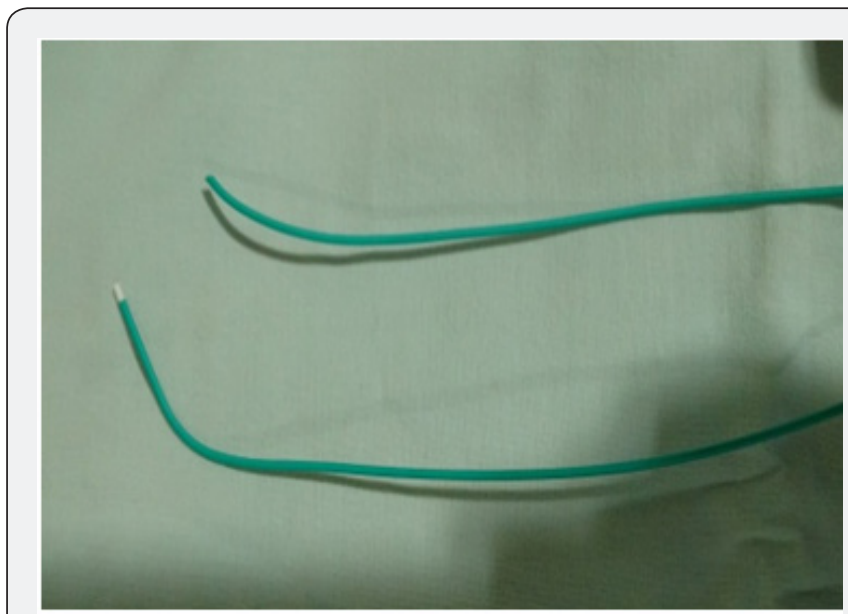

Figure 1: Showing 5Fr MPA catheter cut at the junction of primary and secondary curve. 


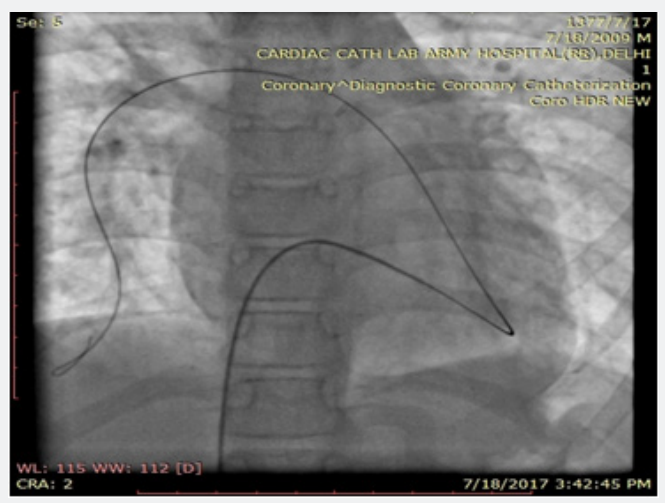

Figure 2: Showing modified catheter tracking over 035terumo wire.

\section{Conclusion}

Complex single ventricle anatomy has varied orientation of pulmonary artery. The pulmonary artery anatomy and pressure are the most important parameters for single ventricle palliation.

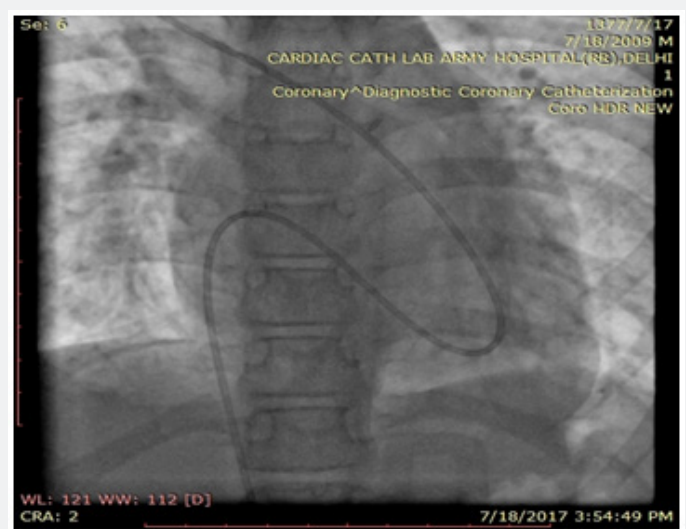

Figure 3: Showing catheter in RPA.

Commonly available catheters may not track over wire due to multiple bends, as what happened in our case. The above modification of end hole multipurpose catheter could reach the pulmonary artery. It can be useful in cath labs to enter pulmonary artery in complex anatomy.

Your next submission with Juniper Publishers will reach you the below assets

- Quality Editorial service

- Swift Peer Review

- Reprints availability

- E-prints Service

- Manuscript Podcast for convenient understanding

- Global attainment for your research

- Manuscript accessibility in different formats

( Pdf, E-pub, Full Text, Audio)

- Unceasing customer service

Track the below URL for one-step submission https://juniperpublishers.com/online-submission.php 